\title{
Perform Pap smear test and Factors affecting on the prevalence of cervical cancer in women at Qazvin, Iran
}

\author{
Asghar Karbord*1, Maryam Rajabi², Shahram Rastak ${ }^{3}$, Mohammad Bokharaei ${ }^{4}$ and Kiamars \\ Karbord $^{5}$
}

${ }^{1}$ MSc epidemiology \& faculty members of surgical technologist group of paramedical college, Qazvin University of medical science, Qazvin, Iran

${ }^{2}$ Assistant professor anesthesiology \& Faculty member of anesthesiology group of Medicine College of Qazvin University of Medical Sciences, Qazvin, Iran.

${ }^{3} \mathrm{MSc}$ anesthesiology \& faculty members of surgical technologist group of paramedical college, Qazvin University of medical science, Qazvin, Iran.

${ }^{4} \mathrm{MSc}$ ICU educational nursing \& faculty members of surgical technologist group of paramedical college, Qazvin University of medical science, Qazvin, Iran

${ }^{5}$ MSc Applied Mathematics. Faculty member of Mathematics school - Hormozgan University, Iran

\begin{abstract}
Background: After breast, skin and long cancers, cervical cancer is the most common cancer in women and is a kind of cancer that can be diagnosed with Pap smear method in pre malignancy stage. Awareness of screening methods of this cancer, have great influence in reducing the incidence and mortality of it.

The aim of this project was to determine awareness, attitude and function of married women, who referred to health centers of Qazvin, about Pap smear and cervical cancer in 2018.

Method and Material: In this cross-sectional study (descriptive-analytical), 300 married women, who referred to health centers of Qazvin in 2018, were selected by classified sampling method and then simple random selection. The study was a questionnaire with 4 part including demographic questions, functional test, attitude and awareness resulting from national Pap smear plan of health minister, which was distributed and completed after confirming the validity and reliability with coordination centers with the help of trained people. The data were analyzed with SPSS 22 software.

Result: In this project that the highest age group were women with $35-45$ years (58\%) with the average age of (36 \pm 8 ) years, awareness about introducing and recognition of pap smear and cervical cancer were $41 \%$ and $46 \%$ respectively.44\% of them have at least once experienced pap smear. $24 \%$ of this number have followed up again after one year.73\% of participants of this project were agree with the test and early diagnosed of cervical cancer.

Conclusion: In order to assess the effect of factors influencing awareness, attitude and function of the women about the cervical cancer and pap smear test, using multiple regression model, it was determined that there is a significant relation between level of awareness and factors including: age, economic situation, job and education $(\mathrm{p}=.05)$. also there is a significant relation between function and attitude and factors including education, age and awareness about disease. This represents a change in policy and education and health infrastructure in the field of knowledge of cancer and the use of modern methods of teaching.
\end{abstract}

Corresponding author: Dr. Asghar Karbord, MSc Epidemiology \& faculty members of surgical technologist group of paramedical college, Qazvin University of medical science, Qazvin, Iran. Tel: 09122893826; E-mail:karbord2003@yahoo.com.

Received: March 02, 2020; Accepted: March 10, 2020; Published: March 14, 2020 
Keywords: Pap Smear, Cervical Cancer, Prevalence

\section{Background}

The most common cancer in the women then breast, skin and lung cancers is cervical cancer. This disease kind of cancer that can be diagnosed with Pap smear method in pre malignancy stage. Awareness of screening methods of this cancer, have great influence in reducing the incidence and mortality of it. The aim of this project was to determine awareness, attitude and functional test of married women, who referred to health centers of Qazvin University of medical science, about Pap smear and cervical cancer in 2018.W.H.O in 2010 diagnosed 7.3 million new cases of cancer in the world that $59 \%$ of these numbers were for developing countries [1]. This number increased to 22 million in 2016 this disease is the third cause of death in developing countries [2]. According to the records of W.H.O 25\% of women death is caused by malignant tumor that $18 \%$ of these numbers were because of cervical cancer [3]. Because on the latest finding $85 \%$ of all cervical cancer causes (493000 cases per year) and also $85 \%$ of deaths caused by this disease (273500cases per a year) were recorded in developing countries [4]. At present time this cancer is responsible for 4.2 million deaths among women between the ages of 25 to 65 in developing countries while this number is 3.0 million in developed countries [5]. In Iran cervical cancer is a common kind of cancer with the outbreak percentage of 64.6 among other cancers [6].The pre-cancer stage of this disease is long and if the patient were to be treated the survival rate is almost 100 percent [7].The role of screening in the first diagnoses of this disease is highly important(8). The role of doing Pap Smear is early diagnosis of changes in precancer stage [9].Screening by Pap Smear is simple cheap and mostly reliable for diagnosis of pre-malignant changes cervical cancer [10]. The Obstetricians College in U.S has recommends this test [11]. Ever woman after the age of 18 or after sexual activity has to take a Pap Smear test per a year .If the test results of Pap Smear and Pelvic examination in 3 years in a row were natural then increasing the distance between the tests by the doctor orders is permitted [12]. By presenting Pap smear as an act of screening. The outbreak of cervical cancer since 1950 has decreased by $79 \%$ and the number of deaths has decreased by $70 \%$ [13]. With consideration of high detection power of Pap smear test and suppleness of it, it is expected that all women attend regularly for this test while in developing countries the number of attendances is not optimal [14]. Even though the Pap Smear has entered Iran's hygiene system since 1991 the studies show that it isn't welcomed in Iran [15]. During the studies which were conducted in Yazd only $51.14 \%$ of women regularly take the test (at least once every 3 years) [16]. A study on Farsan women shows that women between the ages of 30_40 (80\%) have the most awareness and women between the ages of 15_19 (64\%) have least awareness about Pap Smear test that shows the value of awareness examination [17]. Also the information $s$ of a research shows the connection between awareness and cancer screening is not totally clear and needs more studying [18]. On this research we tried to find the most effective reasons on awareness, view and women function about Pap smear and cervical cancer as much as possible and help hygienic managers about improving cervical cancer.

\section{Method and Material}

This research is a cross-sectional study that is analyzed by SPSS20 software. This descriptive research is analyzed to show the level of awareness; view and300 married women function that attended to health centers of Qazvin University of medical science about Pap smear and cervical cancer in 2018.

On that course the questionnaires (made by the researcher) was used. The validity of those questionnaires was confirmed. The data was included of 4 parts such as: 1- demographic questions 2-functional questions 3three optional awareness questions (yes, no) 4-attitude questions that were on Licret5 degree scale then the questionnaires were given and completed by trained people with the coordination of health centers of Qazvin University of medical science. Analyzing the data was performed by SPSS20 program and statistical formulas. In this research we used simple random sampling among appliers. Funds from the questionnaires were uploaded in SPSS20 analyzing system, and then one 
of the statistical formulas was used with the help of statistical professor.

\section{Founds}

On this research that the majority of the age category was women between the ages of 20-30 with the average age of $(31 \pm 6)$ the level of awareness about familiarity and knowing Pap smear was $41 \%$ and cervical cancer was $46 \% .44 \%$ have done Pop Smear exam at least once and $24 \%$ of these applied again. View of $73 \%$ of the participants in the studies was positive and resulted in early recognition.

Table1: Frequency and sig-relation age's group of women with performance Pap smear test.

\begin{tabular}{|c|c|c|c|c|}
\hline Age group & $\begin{array}{l}\text { Pap } \\
\text { smear }\end{array}$ & $\begin{array}{l}\text { frequen- } \\
\text { cy }\end{array}$ & percentage & $\begin{array}{l}\text { p-val- } \\
\text { ue }\end{array}$ \\
\hline \multirow{2}{*}{$\begin{array}{l}\text { Under } 20 \\
\text { years }\end{array}$} & yes & 13 & $\% 29$ & \multirow[t]{8}{*}{0.004} \\
\hline & no & 32 & $\% 71$ & \\
\hline \multirow[t]{2}{*}{$20-30$ years } & yes & 123 & $\% 76$ & \\
\hline & no & 40 & $24 \%$ & \\
\hline \multirow[t]{2}{*}{ 30-40 years } & yes & 50 & $81 \%$ & \\
\hline & no & 12 & $19 \%$ & \\
\hline \multirow[t]{2}{*}{ Over 40 years } & yes & 26 & $87 \%$ & \\
\hline & no & 4 & $13 \%$ & \\
\hline
\end{tabular}

Table 2: Frequency of pregnancy women and sigrelation with performance Pap smear

\begin{tabular}{|c|c|c|c|}
\hline $\begin{array}{c}\text { Number of } \\
\text { pregnancy }\end{array}$ & Frequency & Percentage & P-value \\
\hline None & 20 & $11 \%$ & \multirow{2}{*}{0.000} \\
\hline Once & 60 & $31 \%$ & \\
\hline Twice & 65 & $34 \%$ & \\
\hline Three times & 32 & $17 \%$ & \\
\hline Four times & 8 & $4 \%$ & \\
\hline Five times & 5 & $3 \%$ & \\
\hline
\end{tabular}

Table 3: Frequency of performance Pap smear test in the women

\begin{tabular}{|c|c|c|}
\hline Pop smear & Frequency & Percentage \\
\hline Positive & 190 & $64 \%$ \\
\hline Negative & 110 & $36 \%$ \\
\hline Sum & 300 & $100 \%$ \\
\hline
\end{tabular}

Table 4: Number of performance of Pop Smears test

\begin{tabular}{|c|c|c|}
\hline $\begin{array}{l}\text { Number of Pop } \\
\text { smear }\end{array}$ & frequency & percentage \\
\hline Once & 26 & 28.3 \\
\hline Twice & 16 & 17.4 \\
\hline $\begin{array}{c}\text { More than three } \\
\text { times }\end{array}$ & 14 & 15.2 \\
\hline Not done & 36 & 19.1 \\
\hline
\end{tabular}

Table 5: Summary results of stepwise logistic regression to predict the Pap test performance

\begin{tabular}{|l|l|l|l|l|l|l|}
\hline Variable & $\boldsymbol{\beta}$ & $\boldsymbol{\beta}(\mathrm{SE})$ & OR & \multicolumn{2}{|l|}{$\begin{array}{l}\text { CI-(95\%-In- } \\
\text { terval) }\end{array}$} & $\begin{array}{l}\text { P val- } \\
\mathbf{u e}^{*}\end{array}$ \\
\hline $\begin{array}{l}\text { Pap test } \\
\text { Knowledge }\end{array}$ & 0.28 & 0.35 & 1.13 & 14.05 & 16.11 & $<0.04$ \\
\hline $\begin{array}{l}\text { Cervical } \\
\text { cancer } \\
\text { knowledge }\end{array}$ & 0.23 & 0.18 & 1.09 & 13.79 & 15.83 & $<0.03$ \\
\hline age & 0.03 & 0.01 & 3.27 & 17.91 & 19.01 & 0.000 \\
\hline
\end{tabular}

Table 6: Mean score of knowledge about Pap test and cervical cancer in women

\begin{tabular}{|l|c|c|c|}
\hline Variable & $\begin{array}{l}\text { History of } \\
\text { pap smear }\end{array}$ & Mean SD & \multirow{2}{*}{ P value } \\
\hline $\begin{array}{l}\text { Knowledge about } \\
\text { Pap test }\end{array}$ & yes & $3.21 \pm 1.83$ & \multirow{2}{*}{$<0.03$} \\
\cline { 2 - 3 } & no & $2.05 \pm 0.88$ & \\
\hline $\begin{array}{l}\text { Cervical cancer } \\
\text { knowledge }\end{array}$ & yes & $4.63 \pm 0.93$ & \multirow{2}{*}{$<0.02$} \\
\cline { 2 - 3 } & no & $2.46 \pm 1.8832$ & \\
\hline
\end{tabular}

\section{Results}

Cervical cancer is one of the most important kinds of cancer among women [19]. Early recognition of it is highly effective in reducing the number of deaths and decreasing the rate of the disease, Therefore knowing this method could be effective. The prevalence of cervical cancer is increasing because using Pap smear test more regularly and more comprehensively than in the past [20]. According to the American Cancer Society (2012), the Pap smear test is a routine cancer screening method that should be done every 3 years, and a Pap smear with an HPV DNA test is recommended as a screening method every 5 years [21]. In the present study, most of the low knowledge was detected in patients in the age group between Under 20 years and 
60 years. Low attitude and low suing test were found in $8 \%$ and $9 \%$ of the women in this age group, respectively. The study reported that most of the low knowledge cases $13 \%$, in their study was in the age group of 20-29 years, followed by $35.96 \%$ in the age group of $20-29$ years [22]. High attitude was found in $67 \%$ (age group of 30-40 years) and high using test in 79\% (age group of 30-40 years). Other study reported that high using test was the most common knowledge, found in $47 \%$ of their individuals, followed by attitude in $34 \%$ of the cases [23]. For positive knowledge and using test, the average age of the women was 36 years.

The education and effectiveness: level of education (diploma) 39\% and Masters and higher 24\%. In the conducted research most participants didn't have women diseases (relative abundance of 72.8) and few participants were sick (relative abundance of 27.2). In this study most participants toke Pap smear (relative abundance of 59.8) and the remaining participants (relative abundance of 40.2) didn't take Pap smear. Most number of taken Pap smear exams was once (relative abundance of 28.3) and the lowest taken exams three times (relative abundance of 15.2) and for those who didn't take the exam (relative abundance of 19.1).

\section{Conclusion}

Pap smear testing is a very useful, method, and safe procedure for detecting cervical cancer. It should be established as a routine screening procedure to reduce the treatment burden, morbidity, and mortality. Every woman above the age of 30 years should undergo routine cervical cancer screening, even into the postmenopausal period. The Pap test has been regarded as the gold standard of cervical screening programs.. The community should be educated about the Pap smear test, including its goal and the required frequency of application, by widespread educational and media programs. Most women who visited an outpatient clinic are not aware of cervical cancer screening. Thus, there is a need to spread cancer screening programs to help prevent mortality and morbidity due to cervical cancer [24-28].

\section{References}

1. Benntt VR, Myles MF (2000) "Abnormalities of Early Pregnancy Myles". Textbook for Midwives. 13th edition. Published: Elsevier Australia. Paysh 4: 217-221.

2. Mehdizadeh $\mathrm{K}$ et al. (2005) The effect of education about importance of Pap smear test on teacher's"knowledge's and practices who Work in girl's school in Rafsanjani. Journal of Kerman University of Medical Sciences 5: 71-79.

3. Ferlay J, Bray F, Pisani P, Parkin DM (2004) Globocan: Cancer Incidence, Mortality and Prevalence Worldwide. In IARC Cancer Base No.5, version 2.0, Lyon: IARC Press 3: 94-99.

4. Yang BH, Bray FI, Parkin DM, Sellors JW, Zhang ZF (2004) Cervical cancer as a priority for prevention in different world regions: an evaluation using years of life lost. Int J cancer 109: 418-424.

5. Rezai J (2004) Prevention and Treatment Procedures of Prevalence Cancer in Iran. Tehran Chehr Publish 1: 18-21.

6. Bekmann C, Ling B (2000) Obstetrics and gynecology. 13th Edition Baltimore, Williams \&Willkins: USA 345: 700-711.

7. Halakoi Naini K, Chinichian M, Ghazizadeh Ehsai SH, Sadeghi Pour H, Refai Shir Pak KH (2004) The reason for women to be treated and the Pap tests should be repeated. Journal Paysh 1: 137-131.

8. Matteson PS (2001) Women's health during the childbearing years, a community based approach. ST. Louis: Mosby 6: 417-422.

9. Mirza Khani K (2005) The effect of ordering in endocervix-exocervix sampling on Pap smear result. Journal of sabzevar school of medical sciences 2: 36 41.

10. Trubeaux AL and Proche DJ (2000) Women's heaith. In: Stanhope M, Lancaster J .Community and public health nursing .5th Ed .st. Louide: Mosby 22:189196.

11. Rayan KJ, Berkowilz RS, Babieri RL, Dunaif A (2008) Kistner's Gynecology \& Women's health. Translate by: Ghazijahani B, Ghotbi R. 7th ed. Theran: Golban; 2008: 128-129.

12. Hatch KD, Berek JS (2002) intraepithelial disease of the cervix, vagina and valve. In: Berek Js .Novak's 
Gynecology, 13th edition. Philadelphia: Lippincott Williams \& willkins 36: 24-29.

13. Chirenje ZM, Rusakaniko S, Kirumbi L, Ngwalle EW, Makuta-Tlebere P, et al. (2001) Situation analysis for cervical cancer diagnosis and treatment in east, central and southern African countries. Bull World health organ 79: 127-232.

14. Yosofi Z, Macinai M (2004) Cervical intra-epithelial neoplasia: analysis of incidence, risk factors and management of these patients. The Iranian Journal of obstetrics, Gynecology and Infertility 1: 32-37.

15. Enjezab B, Faraj Khoda T, Bokael M (2004) Barriers and motivators related to cervical and breast cancer screening. Journal of shahid sadoughi university of Medical Science 3: 78-84.

16. Torabi Farsani F, Jamshidi Z (1999) The survey of practice attitude women 15-49 years on the pop esmir test, medical journal of shahid sadooghi Yazd 1999: 45-49.

17. Pamirez AG, Surezl T laufmanl, Barroso C, Chalela P (2000) Baylor college of Medicine, San Antanio, Texas USA .Am Health promot 14: 292-300.

18. Baghiani MH (2003) The survey of KAP of married women 15-49 years in Yazd for pop esmir test, scientific-research journal of medical science university of Mazandaran, 2003 40: 79.

19. Bakogianni GD, Goutsou SC, Liti MV, Rizopoulou SI (2012) Nikolakopoulos KM, NikolakopoulouM. Knowledge, attitude,and practice of cervical cancer screening among Greek studen ts: a short report. Int J Adolesc Med Health 24: 329-330.

20. Tabeshan A, FIruze F (2008) (effectiveness health education of pap smire test for prevent of cancer in Esfahan high school), Medical journal of Azad university 19: 43-48.

21. Demirtas B, Acikgoz I (2013) Promoting attendance at cervical cancer screening: understanding the relationship with Turkish women's' health beliefs. Asian Pac J Cancer Prev 14: 333-340.

22. Daley E, Perrin K, Vamos C, Hernandez N, Anstey E, et al. (2013) Confusion about Pap smears: lack of knowledge among high-risk women. J Womens Health 22: 67-74

23. Soltan Ahmadi ZH, Abas Zade A, Tir Gari B (2014) The survey of knowledge screening of pap smir \& breast cancer of young daughter in kerman) 2014: 64-69.

24. Enjezab B, Faraj Khoda T, Bakayi M (2004) Determinant of problem screening of GYN on the women of pregnant). Medical journal of medical university of Shahid Sadughi Yazd 73: 78.

25. Taylor VM, Yasui Y, Nguyen TT, Woodall E, Do HH, et al.(2009) Pap smear receipt among Vietnamese immigrants:he importance of health care factors, Ethn Health 14: 575-589.

26. Shakiba Zade E, Ahmadnia E, Akbari F, Negarande $R$ (2009) Barresi mavane va avamele angize saz moaser bar moraje zanan baraye anjam azmayeshe gharbalgari pop esmir], medical journal of nursing and midwifery faculty of medical science university 1387: 84-89.

27. Tomi F. Akinyemiju (2012) Socio-Economic and Health Access Determinants of Breast and Cervical Cancer Screening in Low-Income Countries: Analysis of the World Health Survey. PLoS One 7: e48834.

28. Holakuyi Naeeni K, Chini Chian M, Ghazi Zade Ehsaee SH, Sadeghi Poor HR, Refaee Shir Pak KH (2009) Mozue elal adame moraje zanani k bar asase azmayeshe pop esmir bayad tahte darman va pop esmire mojadad gharar begirand], Faslname Payesh, third year 2: 131-137.

Copyright: @2020 Asghar Karbord et al. This is an open-access article distributed under the terms of the Creative Commons Attribution License, which permits unrestricted use, distribution, and reproduction in any medium, provided the original author and source are credited. 